\title{
Metaphor in Azerbaijani and Russian Media Discourse
}

\author{
Ulviyya H. Taghiyeva ${ }^{1}$ \\ ${ }^{1}$ Department of General Russian Linguistics, Baku Slavic University, Baku, Azerbaijan \\ Correspondence: Ulviyya H. Taghiyeva, Department of General Russian Linguistics, Baku Slavic University, \\ Baku, Azerbaijan. E-mail: u_tagiyeva@yahoo.com
}

Received: August 28, $2015 \quad$ Accepted: November 6, $2015 \quad$ Online Published: November 30, 2015
doi:10.5539/ijel.v5n6p141
URL: http://dx.doi.org/10.5539/ijel.v5n6p141

\begin{abstract}
The paper aims to study the role of metaphors in the construction of Azerbaijani and Russian media discourse. It speaks of the fact that metaphor plays a central role in the structure of discourse. Being the unit of the second nomination, metaphor carries out greater expressive function. Metaphoric expression is always directed to attain the maximal communicative effectivity. This situation makes the metaphor an organizing centre of discourse of any type.
\end{abstract}

Keywords: metaphor, discourse, expression, communication, centre, concept, model

\section{Introduction}

Conceptual Metaphor during the last decades is constantly in the focus of attention of investigators and has established its own discourse. Metaphor is so often and individually spoken of that one may think of it as something unique which has recently attracted the attention of many researchers. As a matter of fact semiotic structure and functional importance of metaphors always gained a leading role in the discourse of any type. At present, sometimes people make discoveries related to the role of metaphors in speech, mentioning the fact that it is associated with the peculiarities of the cognitive mechanism. (Eloeva et al., 2014) If it is so, then we can say that metaphor bears appropriate and obligatory character. Putting in other words, it would be strange if it were absent.

It is known to all that thinking of a person bears associative character. Mechanism of cognition of surrounding us the world is such that without comparison it is impossible to cognize something. Just for that reason such a negative phenomenon as prejudice associated with comparison takes place. We are rather often taught the past knowledge, not giving way to attain the essence of something new. That's why A. Einstein used to say that the greatest scientific heroism of Kepler is that he managed forgetting all which he was thought. T. Run's words are also well-known which he said that new always seems to be nonsense on the ground of the old, nevertheless time passes and new becomes a norm while the old is cognized as nonsense.

It is clear that comparison of the old, which is known to us with the unknown to us the new must have a background. Such a basis for the comparison is considered general feature, i.e. the sign observed in the both classes of the compared objects.

\section{Theoretical Background}

Study of discourse of any type, including the media discourse, shows that metaphor always occupies a leading place in the type of discourse.

Such a status of metaphors in the space of discourse, as we think is conditioned by its role in the structure of communication. The fact is that communication envisages assessment of any component just from the view of communicative effect. Communicative effect in its turn is determined by functional adequacy of the used sign means of the communicative intentions of the speaker. Consequently, the speech is permanently oriented to the production of metaphor (Lakoff \& Johnson, 2003). This makes it necessary to study the process of production of metaphor just in the process of discourse. The more metaphor seems to be appropriate and necessary element of discourse and correspondingly communication, the more it obtains a special status in the frame of cognition. Certainly, metaphor surmises language and speech differentiation too.

In this field it is also important to determine steady usual models of formation of metaphor, and also formation of concrete metaphors. But in the field of formation of metaphors, we think, even accidental speech facts possess 
important value. We think that significance of accidental and speech facts can be determined only from the view point of communicative affectivity in the frame of discourse. On the other hand, if concrete discourses establish relatively steady discussable practice in the space of this or that culture, then usual and occasional facts should be valued in the frame of discoursed practice, but not the language and speech in their accepted means of understanding. Relevancy of sign in the frame of discoursed practice should be determined by its "usefulness". We should also take such a moment as "durability" and "incompleteness" of the discoursed practice, into consideration. The border of discourse is determined ideologically, but not as to the time, accordingly, to speak about its completion is always difficult (Wodak, 2009). Nevertheless, study of metaphor in the structure isactual and that's why uncompleted discoursed practice is very important. Even already taken place discoursed practice is evolution in all the possible aspects. Consequently, character of metaphoric models and concrete metaphor can be considered as an indicator of objective political picture, taking place in the society (Musolff, 2004; Mammadov, 2010). Political metaphors in the widest sense are priorities which are directly discovered in the formation of metaphors or even in the stabilities of metaphoric fund.

From the viewpoint of communicative effect of metaphor it is important that they are brightest representatives of the second nomination.

As it is known to us the essence of the second nomination lies in the fact that the thing possessing its own special name, as to this or that reason begins to be also named by the name of another thing. Why it happens it is not easy to explain. Language possesses great arsenal of means, to state the name of this or that reality. Asymmetry of language code stimulates formation of such a phenomenon as synonymy, oriented to express smallest shades of meaning. All these bear special and particular character and just for this reason, it is not so easy to explain the real meaning of metaphors, signs transferring to objects, possessing their own names not demanding, not surmising other names. In this case the only logically correct explanation which comes to our minds is the realization of aesthetic function. More over aesthetic function of metaphors in this case should not be identified exclusively by finer things. If it in the first place, universal model should work, according to which all the fine things seem to be useful for all. The unit of second nomination of special nomination which precedes the metaphor, entirely carrying out its function, speaks of the fact that metaphor as it is, serves not to the nomination but the expression. Metaphor is not a name, but it is the expression of attitude to the designated. Expression of attitude is always expressive. Still brighter this is introduced in the structure of the metaphor as to the model of animal-human being. It is clear that in the informational altitude the naming of an animal is more in comparison with the name of human being i.e., the semantic structure of the names of animals does not possess any differential seme related to the semantic structure of the name of human being. The main basis for the comparison is of abstract and figurative character. So metaphor "wolf" related to human being does not discover differential semes, basing upon the real community, that's why the correlation itself is of figurative character. Wolf can be neither blood-thirsty, grasping nor cruel. Animals act as to immanent instincts inherent to them. Dividing animals as to these qualities, we factually transfer them to the qualities of human beings. However transferring the qualities of human beings to the animals, we create the character of an animal, which gives us possibility accordingly to transfer the name of an animal to a human being. In all the cases, consideration of correlation of animal and human beings before everything arises expressive function of expressing the attitude to the object, to its quality, to its foreign or internal characteristics. As the basis for comparison becomes some associative feature (not real common feature, but only the feature on which association is symbolically grounded) it is considered in the first plan in the structure of metaphors. Consequently, metaphor in the discourse creates some outbursts directed to excite shock of the addressee. Such kind of shock certainly is not a purpose, nor is an aesthetic means. Metaphor bears purely pragmatic character and it is functionally directed to the adequate cognition of the information. Consequently, the structure of the discourse of the metaphors contains the islands of expressions and maximal communication effect. Efforts are kept from metaphor to metaphor ensuring the necessary level of expression of discourse as a whole. Such an understanding of the role of metaphor is associated with its functional peculiarities and at a certain degree pushes its conceptual character to the back plan. As far as the conceptual contents of metaphor are concerned, it is apparent and as to us does not require special consideration.

\section{Metaphor as Conceptualization in Media Discourse}

Based on the informative function of language, media discourse is defined as an instructional (Wodak \& Busch 2004). At the same time, any genre of media discourse can be hardly be entirely informative, i.e. its certain genre or part of it must imply subjectivity.

Media discourse has strong pragmatic and cognitive potential to create a specific environment over the event it covers. The stories about people's private lives, whether, they are eminent or not, attracts more attention than 
other types of news. Moreover, many genres of media discourse namely news and magazine articles, advertisement and others are supposed person (Talbot, 2007; Mammadov, 2014) to share associations as discursive strategy used by author of media text. Surely, there are a great variety of other discursive strategies used in media text to represent person. It's very striking to contemplate how senders of newspapers and magazine articles, letters, interviews, advertising text etc., use and even manipulate those distinct features of media text and its varies genres involving specific discursive strategies and relevant linguistic devices such as personal possessive and reflexive pronouns.

Comparison of two classes of phenomena is of already conceptual character. As it has been mentioned above, the basis for comparison lying on the basis of metaphor is of figurative character. Just in this lies the main difference between metaphor from any other type of transference, including metanomy which does not yield to metaphor neither in popularity, nor frequency. Of usage Modern Azerbaijani Media discourse witnesses of the fact that metaphors are often used in the titles of articles. In this case the character of unexpectedness strengthens which simultaneously causes to attract the attention of the listener. Metaphor in such cases includes the strategy of discourse, the contents of which are revealed in the text. Metaphor in the headlines is akin to the basic understanding of the frame, because the metaphor given in the headline stimulates to hear what is expected to. At this time it seldom appears as an original intertext, allusion and naturally must be demanded because in the opposite case mechanism of expression won't work. For example, "Manifest of driver" (Baku post, 2012) is associated with the "Manifest of the Communist Party" of K. Marx and f. Engels. The basis of the nominative meaning of the word "Manifest" in the brief academic dictionary "Словарьрусскогоязыка"(The dictionary of the Russian language; Oxford Advanced learner's Dictionary, 2006) is determined as the "written address of the supreme power to the population in the cases when the given information is exclusively important" (The dictionary of the Russian language). The structure of the main nominative meaning appears within the competence of the second nomination with one sign or with one seme, the seme of "importance", i.e. "manifest" bears the information of exclusive importance. For the consideration of newspaper headlines as it was mentioned above, the association with the "manifest of the Communist Party" as a basis for metaphorization is the second meaning of the word "Manifest" "Written address of political parties, social organizations, possessing character of a programme" (The dictionary of the Russian language). So, here two semes are actualized: "address" and "programme". The important fact is that the address of such discourse is all in all, the people of older generation. Such kind of metaphors are associated with the ideology of the past, they can also contain a certain portion of meaning of irony as well. Moreover irony and even a part of comical meaning, here bears only a shade of meaning. The main meaning of "Manifest" remains unchanged. This is extraordinarily serious appeal, moreover it is a challenge, in this case it is a challenge to passersby to be more careful when passing the road. Newspaper Baku-Post is one of the leading newspapers published in modern Azerbaijani. It is issued in the Azerbaijani and Russian languages. In the both languages Baku Post gives advantage to the play of words. We can say that metaphorization of the discourse introduces the brighter characteristics of discourse Baku post. Let us discuss only one of the examples published in the newspaper "Baku Post" in 2012 an article which was called "İşləyən və işləməyən başlar" (C.12) (Working and not working heads) was published. The article was devoted it a football match. The goal, hit by the rival of "our" team was hit with the head. This condition gives possibility for the author of the article to name the headline of the article like this: "Working and not working heads". It is hard to cognize what this hint to the intellectual "damage" of the team which has lost the game is motivated with. We think that is just the aim of metaphor. It is hard to cognize, because not always football team loses the game to the rival team which exclusively intellectually is superior in comparison with the first one. Intellect has nothing to do here. However, here for us the important point is that the given discourse discovers the following advantageous tendency to the metaphorization. Putting in other words feeling the possibility of playing on the words, the sender of the information does not think on the problem how logically the metaphor sounds (leaving alone how ethic the metaphor is). The sender of the information speculates on the "finding" and here is the concluding sentence of the article. "Bakılılar II küncdən zərbəni başa verdi, murska-sobotalilar isə birgə dəfə" korner" özü gördü ki, onu da başla tamamladılar. Beləcə, baş işlətmək lazım gələndə baş itirmək "Bakıya baha başa gəldi" ("Baku" players did not take advantage of eleven "corners" but "murska-sobotius" only once gained the right to "corner" and completed it with a goal. This is the result, when it was necessary to play with the head "Baku" players lost their heads which were too dear for them. Even the page on which the article has been published breathes with pleasure, which the journalist got by using three-fold usage of the word "baş" head

Generally speaking, in the modern media-discourse special problem is the problem of stylistics. As a whole we observe the lowering of stylistic level. It is necessary to note that the given problem is not subjected to the simplest explanation. For example, we should simply say, that the language of newspapers and journals, radio 
and television become rougher, at a great degree come nearer to popular language. We think, here we may distinguish several causes.

The first reason is that the language of media is really greatly democratic. It is impossible to compare it with the discourse of the soviet period of ruling. In those years strict control of ideology was spread even to the costumes of tele broadcaster. Today refusal from the several norms becomes a means of advertizing and self advertizing in itself. Here we meet another type of matter, in which the sender of information in discourse often gives the information which is not admitted to reveal. This is just the matter of taste which has already become an ordinary occurrence.

The second reason is the lowering of the style which is supported in the western examples and even in this case, our media is incapable to choose the best ones. The criterion of choice, as a rule, serves to the personal taste. The absence of true professionalism does not make it possible to choose the best specimens of speech and behavior, mimics and gestures, which are characteristic for the world including western media discourse as well.

At last, the third reason bears more programmed character. The sender of the discourse feels, even if he/she is not able to understand this in the reflexive level, then the lowering of style makes it possible to raise the level of expression. This is an exceedingly an aesthetic phenomenon. Expression in its direct means makes it possible to raise the communicative effectiveness of discourse. This speaks already of achieving special aim by the sender adequacy of the cognition. It is clear that under the term adequacy here it is necessary to understand not the deeper meaning of the contents of discourse or its hidden intentions, but understanding by the sender of the information which the sender wishes to send.

\section{Conclusion}

Overall its clear from the data provided that analysis of the media discourse witnesses of the fact that metaphor formation possessed a dominating process, in which exactness and informativity are victimized. It is necessary to note one more actual moment in the given context. Auditorium which the sender of the information of lowered discourse gathers is a great deal more in number as public speech meets the requirement of wide mass of people. We think here, longing for increasing communicative affectivity of speech plays its role. In addition conceptual metaforing still one of the vital issues.

\section{References}

Eloeva, F. A., Perekhvalskaya, E. V., \& Sausverde, E. (2014). Metaphor and heuristic function of the language. Linquistics Questions, 1.

Lakoff, G., \& Johnsen, M. (2003). Metaphors we live by. London: The university of Chicago press. http://dx.doi.org/10.7208/chicago/9780226470993.001.0001

Mammadov, A. (2010) Metaphors in American and Russian political discourse. Rask Journal, 31.

Mammadov, A. (2014). Deitic representation of person in media discourse. De Gruyter. Berlin-New York.

Musolff, A. (2004). Metaphor and political discourse: Analogical reasoning in debates about Europe. London: Palgrave Macmillan. http://dx.doi.org/10.1057/9780230504516

Oxford Advanced Learner's Dictionary. (2006). Oxford University Press.

Russian Dictionary. (1982). Tom 2. M.: Russian.

Talbot, M. (2007). Media discourse: Representation and interaction. Edinburg: Edinburg University Press.

Wodak, R. (2009). The discourse of politics in action. Politics as usual. London: Palgrave Macmillan. http://dx.doi.org/10.1057/9780230233683

Wodak, R., \& Brigitta, B. (2004). Approaches to media text. In J. D. H. Downing, D. McQuail, P. Schlesinger, \& E. Wartella (Eds.), The Sage Handbook of Media Studies. London: Sage.

\section{Copyrights}

Copyright for this article is retained by the author(s), with first publication rights granted to the journal.

This is an open-access article distributed under the terms and conditions of the Creative Commons Attribution license (http://creativecommons.org/licenses/by/3.0/). 